\title{
Dietary microbial muramidase improves feed efficiency, energy and nutrient availability, and welfare of broilers fed commercial type diets containing exogenous enzymes
}

By Pirgozliev, V., Simic, A., Rose, S.P. and Perez Calvo, E.

Copyright, publisher and additional information: .This is the authors' accepted manuscript. The published version is available via Taylor \& Francis.

Please refer to any applicable terms of use of the publisher

DOI link to the version of record on the publisher's site

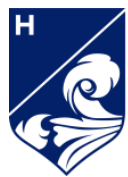

Harper Adams University 


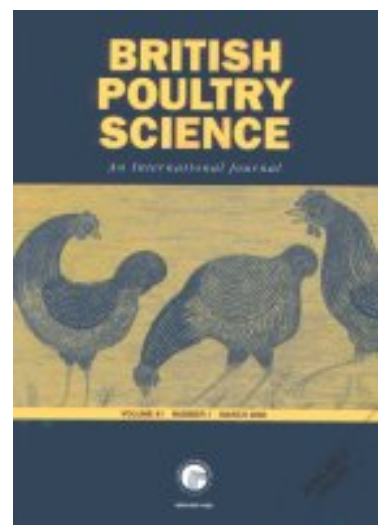

\section{Dietary microbial muramidase improves feed efficiency, energy and nutrient availability, and welfare of broilers fed commercial type diets containing exogenous enzymes}

\begin{tabular}{|r|l|}
\hline Journal: & British Poultry Science \\
\hline Manuscript ID & CBPS-2020-173.R3 \\
\hline Manuscript Type: & Original Manuscript \\
\hline Author: & 07-Jul-2020 \\
\hline Complete List of Authors: & $\begin{array}{l}\text { Pirgozliev, Vasil; Harper-Adams University College, Animals; } \\
\text { Simic, Antonija; Harper-Adams University College, Animals } \\
\text { Rose, Stephen; Harper Adams University College, National Institute of } \\
\text { Poultry Husbandry } \\
\text { PÉREZ CALVO, Estefania; DSM Nutritional Products France }\end{array}$ \\
\hline Keywords: & $\begin{array}{l}\text { Muramidase, Feed efficiency, footpad dermatitis, metabolizable energy, } \\
\text { Broilers }\end{array}$ \\
\hline &
\end{tabular}

\section{SCHOLARONE Manuscripts}




\section{Dietary microbial muramidase improves feed efficiency, energy and nutrient availability,} and welfare of broilers fed commercial type diets containing exogenous enzymes

${ }^{1}$ NIPH, Harper Adams University, Newport, Shropshire, UK

${ }^{2} D S M$ Nutritional Products, Animal Nutrition \& Health $R \& D$, Village-Neuf, F-68128

Corresponding author: Dr V. Pirgozliev

Email: vpirgozliev@harper-adams.ac.uk

The National Institute of Poultry Husbandry, Harper Adams University, Newport, UK

\section{Abstract}

1. The aim of this study was to evaluate the effect of graded levels of the microbially-derived feed lysozyme, muramidase (MUR) on feed intake (FI), weight gain (WG), feed conversion ratio (FCR), European Performance Index (EPI), dietary N-corrected apparent metabolisable energy (AMEn), footpad dermatitis score (FPD) and other welfare variables, when fed to broilers from 0 to $42 \mathrm{~d}$ age.

2. A four-phase dietary program and four experimental pelleted diets were used; a control diet (following breeder recommendations without MUR supplementation), and three diets based on the control diet supplemented with 25,000, 35,000 and 45,000 LSU (F)/kg of MUR, respectively. In addition, all experimental diets contained exogenous xylanase, phytase and a coccidiostat. Each diet was fed to birds in 24 pens (20 male Ross 308 chicks in each pen) following randomisation. Dietary AMEn was determined at $21 \mathrm{~d}$ of age, and FPD was evaluated at the end of the study. Data were analysed by ANOVA, using orthogonal polynomials for assessing linear and quadratic responses to MUR activity.

3. The inclusion of MUR did not change FI $(\mathrm{P}>0.05)$, but increased WG in a linear manner $(\mathrm{P}<0.05)$ and reduced FCR in a quadratic manner, with optimum WG and FCR observed in birds fed approximately $35000 \mathrm{LSU}(\mathrm{F}) / \mathrm{kg}$. In accordance with the improvement in FCR, 35000 LSU (F)/kg MUR supplementation produced the highest EPI $(\mathrm{P}<0.05)$. FPD score was 
30 linearly decreased with increased addition of MUR $(\mathrm{P}<0.05)$. Dietary AMEn responded in a

31 quadratic fashion to the MUR inclusion, as the highest values were obtained with the highest

32 inclusion rate $(\mathrm{P}<0.05)$.

33 4. In conclusion, the results showed that inclusion of MUR improved feed efficiency and the 34 foot health of birds.

35

36

37 Key words: Muramidase, feed efficiency, metabolisable energy, footpad dermatitis. 


\section{Introduction}

The use of feed additives to improve the efficiency of growth and/or egg production, prevent disease and improve feed utilisation is a common strategy to improve efficiency in the poultry industry (Pirgozliev et al., 2019). Exogenous enzymes are the most commonly used feed additives. The enzymes widely used by the industry are non-starch polysaccharidases that cleave the non-starch polysaccharides in viscous cereals and microbial phytases that target the phytate-complexes in plant ingredients (Pirgozliev et al., 2010; Adeola and Cowieson, 2011; Ravindran, 2013). Recently a new category of feed enzymes, microbial muramidase (MUR) have become available, in which the substrate is not present in the feed but already present in the gastrointestinal tract. Muramidases (EC 3.2.1.17), also known as lysozyme or Nacetylmuramidase, are naturally found in a great variety of animal secretions, plants, or microorganisms. Muramidases are glycosyl hydrolytic enzymes that cleave the $\beta-1,4$ glycosidic linkages between $\mathrm{N}$-acetylmuramic acid and $\mathrm{N}$-acetyl glucosamine in the carbohydrate backbone of bacterial cell wall components, called peptidoglycans (PGNs). Recent studies have demonstrated the efficacy of microbial MUR on feed efficiency and gastrointestinal tract functions, enhancing nutrient digestibility and absorption (Goodarzi Booronjeri et al., 2019; Sais et al., 2019). Lichtenberg et al. (2017) suggested that catalysing the depolymerisation of PGNs from the bacterial cell debris present in the gut, as a result of the continuous bacterial turnover, may best describe the mode of action of this enzyme. During this process, $50 \%$ of the pre-existing PGNs in a bacterial cell are released from the wall and recycled within one generation (Reith and Mayer, 2011), although the fate of the remaining 50\% is unclear. It can be speculated that accumulation of bacterial cell wall fragments at the gut surface could impair nutrient digestion and absorption and, in that case, the inclusion of microbial MUR in broiler diets could result in better nutrient availability and higher growth performance (Goodarzi Boroojeni et al., 2019). Thus, the combined application of different categories of enzymes in 
64 commercial poultry diets may result in additive or synergistic effects on nutrient utilisation and

65

66

67

68

69

70

71

72

73

74

75

76

77

78

79

80

81

82

83

84

85

86

animal performance.

The present study investigated the impact of different inclusion levels of microbial MUR on growth performance, including feed intake (FI), weigh gain (WG) and feed conversion ratio (FCR), dietary N-corrected apparent metabolisable energy (AMEn), dry matter (DMR), organic matter (OMR), nitrogen (NR) and fat retention (FR) coefficients, sialic acid (SA) in excreta, foot bad dermatitis score (FPD), European poultry efficiency factor (EPEF) and some litter quality variables when fed to broilers from 0 to $42 \mathrm{~d}$ age.

\section{Materials and methods}

The experiment was conducted at the National Institute of Poultry Husbandry (NIPH) and approved by the Research Ethics Committee of Harper Adams University, Newport, UK.

\section{Animals and experimental design}

A total of 1960, male, Ross 308 broilers were obtained from a commercial hatchery (Cyril Bason Ltd, Craven Arms, UK). On the arrival, 1920 birds were divided into 96 floor pens with 20 birds in each (excluding ill and malformed birds). Each of the 96 pens had a solid floor and measured $2.1 \mathrm{~m}^{2}$ and bedded with wood shavings.

81 The room temperature was approximately $32^{\circ} \mathrm{C}$ at day old and was gradually reduced to about $20^{\circ} \mathrm{C}$ at 21 days of age. A standard lighting program for broilers was used, decreasing the light:dark ratio from $23 \mathrm{~h}: 1 \mathrm{~h}$ from one day old to $18 \mathrm{~h}: 6 \mathrm{~h}$ at seven days old, which was maintained until the end of the study. Access to feed and the water was ad libitum.

Four starter (day 1 to 10 ), grower (day 11 to 20), finisher-1 (day 21 to 35) and finisher-2 (day 35 to 42 ) wheat-soybean diets were produced (control; C), three containing different levels of 
microbial MUR (Balancius ${ }^{\mathrm{TM}}$, DSM Nutritional Products Ltd, Kaiseraugst, Switzerland); low (L, $417 \mathrm{~g} / \mathrm{t} ; 25,000 \mathrm{LSU}(\mathrm{F}) / \mathrm{kg}$, medium (M, $583 \mathrm{~g} / \mathrm{t} ; 35,000 \mathrm{LSU}(\mathrm{F}) / \mathrm{kg})$, and high (H, $750 \mathrm{~g} / \mathrm{t}$; 45,000 $\mathrm{LSU}(\mathrm{F}) / \mathrm{kg})$. Each single unit of $\mathrm{LSU}(\mathrm{F})$ is defined as the amount of enzyme that increases the fluorescence of $12.5 \mu \mathrm{g} / \mathrm{ml}$ fluorescein-labelled peptidoglycan per minute at $\mathrm{pH}$ 6.0 and $30 \mathrm{C}$ by a value that corresponds to the fluorescence of approximately $0.06 \mathrm{nmol}$ fluorescein isothiocyanate isomer I.

The tested MUR product was included in powder form with a minimum analysed MUR activity of $60,000 \mathrm{LSU}(\mathrm{F}) / \mathrm{g}$ product. Diets were supplemented with exogenous xylanase (RONOZYME ${ }^{\circledR}$ WX, endo-1,4-beta-xylanase; DSM Nutritional Products Ltd, Kaiseraugst, Switzerland), phytase (RONOZYME ${ }^{\circledR}$ HiPhos; DSM Nutritional Products Ltd, Kaiseraugst, Switzerland) and coccidiostat (CLINACOX ${ }^{\circledR}$, Elanco Ltd., Guelph, CA). No antibiotic was included in feed during the experimental period. The diets were isocaloric and isonitrogenous for each feeding phase, and met or exceeded breeder recommendations (Aviagen Ltd, Edinburgh, UK). The composition of the experimental diets is shown in Table 1.

Table 1 here

Mortality was recorded daily. A visual assessment for litter score of the entire pen was performed at $34 \mathrm{~d}$ old, using a five point scoring system, from 1 to 5 , as previously described (Da Costa et al., 2014; Mirza et al., 2016). A lower score indicated better litter quality. The litter $\mathrm{pH}$ was determined at $35 \mathrm{~d}$ of age using a $\mathrm{pH}$ probe with a stainless steel penetration blade directly into the litter in four different sides in each pen. The $\mathrm{pH}$ probe was attached to a Hanna HI 99163 meter (Hanna Instruments Ltd, Bedfordshire, UK). Litter dry matter was determined at $35 \mathrm{~d}$ of age by taking five samples from the same locations of the floor in each pen, including 
111 the area near the drinker, and drying them in an oven (see method below). The samples were

112 then homogenised, milled and stored dry before further analysis.

113 Footpad and hock lesions were assessed and given a score at $35 \mathrm{~d}$ of age for both the left and

114 right leg of all birds, and classified according to a scale published by Hocking et al., (2008)

115 from 0 (no lesion) to 4 (very severe lesions). A mean value per pen for each of the 116 measurements was used in statistical analysis.

117 At $17 \mathrm{~d}$ of age, two randomly selected birds from each pen were transferred to one of 96 raised118 floor battery pens $(60 \times 60 \mathrm{~cm}$ floor area $)$ in a controlled environment room. Each pen was 119 equipped with a metal feeder, providing $40 \mathrm{~cm}$ feeding space, and two nipple drinkers with 120 spill cups. Treatments were randomly allocated to the pens. Feed and water were offered for 121 ad libitum consumption. The selected birds were kept in the pens for $72 \mathrm{~h}$, and total excreta 122 were collected three times (every $24 \mathrm{~h}$ ) from the trays beneath, and spilled feed and feathers 123 were removed before weighing. Feed intake was weighed for the same period. The N-corrected 124 apparent metabolisable energy (AMEn) of diets was determined following the procedure of 125 Hill and Anderson (1958).

126 The coefficients of apparent retention of dietary dry matter (DMR) and N (NR) retention 127 coefficients were determined as the difference between nutrient intake (feed intake multiplied 128 by the nutrient content in feed) and nutrient output (excreta voided for $72 \mathrm{~h}$ multiplied by the nutrient content in excreta) divided by the nutrient intake.

130 The European Poultry Efficiency Factor, which standardises technical results by considering 131 FCR, mortality and daily weight gain, was determined for the broilers from 0 to $42 \mathrm{~d}$ age.

\section{Chemical analysis}

133 Dry matter in litter, feed and excreta was determined by drying samples in a forced draft oven 134 at $105^{\circ} \mathrm{C}$ to a constant weight (AOAC 2000; method 934.01). Crude protein $(6.25 \times \mathrm{N})$ in litter, 
135 feed and excreta samples was determined by the combustion method (AOAC 2000; method 136 990.03) using a LECO FP-528 N (Leco Corp., St. Joseph, MI, USA). Oil (as ether extract) was 137 analysed using diethyl ether by the ether extraction method (AOAC 2000; method 945.16) 138 using a Soxtec system (Foss Ltd., Warrington, UK). The gross energy (GE) values for feed and 139 excreta samples were determined in a bomb calorimeter (model 6200; Parr Instrument Co., 140 Moline, IL, USA), with benzoic acid used as the standard.

141 Endogenous mucin in the dry excreta was measured using the concentration of the SA as a 142 marker, following the periodate-resorcinol method (Jourdian et al., 1971). In brief, the method 143 involves conversion of free and glycosidically bound SA to chromogenic substances, by 144 treatment with periodic acid followed by resorcinol. The colour of the samples was stabilised 145 by 2-methyl-propan-2-ol, and, after centrifugation, the absorbance of the supernatant was 146 determined spectrophotometrically at $630 \mathrm{~nm}$ (Spectronic 301; Milton Roy Company, 147 Warminster, PA). This procedure detected total, free, and glycosidically bound $\mathrm{N}$ acetyl 148 neuraminic (sialic) acid. The MUR activity in the feed samples was determined according to 149 the method described by Lichtenberg et al. (2017).

\section{Statistical analysis}

151 Prior to statistical analyses, data were checked for normality and homogeneity, and 152 transformations were deemed not necessary. Statistical analyses were performed using GenStat 153 (18 $8^{\text {th }}$ edition) statistical software package for Windows (IACR, Rothamstead, Hertfordshire, 154 UK). The comparison between the experimental results was performed by ANOVA, using 155 orthogonal polynomials for testing linear and quadratic responses to MUR inclusion. 156 Differences were reported as significant at $\mathrm{P}<0.05$, and trends towards significance $(\mathrm{P}<0.1)$, 157 were included in the report. 
159

160

161

162

163

164

165

166

167

168

169

170

171

172 During the first three weeks of the feeding trial there were no effects $(\mathrm{P}>0.05)$ of diet on any 173 growth performance variables, although birds fed the control diet tended $(\mathrm{P}=0.053)$ to have the 174 lowest WG during the starter phase (1-10 d; Table 3).

175 A change in performance was observed at $35 \mathrm{~d}$ of age when weight gain of the birds was 176 improved in a significant linear fashion $(\mathrm{P}<0.05)$ with increasing MUR dosage. The high 177 dosage of MUR gave the lowest FCR, although the response was curvilinear $(\mathrm{P}<0.05)$, i.e. low 178 MUR dosage produced a higher FCR compared to medium and high dosages. Overall, for the

179 entire period from one to $42 \mathrm{~d}$ of age, weight gain increased in a dose dependent linear manner 180

\section{Results}

The birds remained healthy throughout the study period. No adverse effects due to feeding the experimental diets were observed, and the overall mortality was low at $3.4 \%$ and not treatment related. The determined chemical composition of the diets is presented in Table 1 and agreed with the calculated values.

Table 1 here

Results of analyses of MUR activity in the diets confirmed the correct addition of the product within the range of the expected values $\pm 20 \%$ (Table 2 ).

Table 2 here $(\mathrm{P}<0.001)$. The significant quadratic response of FCR at $42 \mathrm{~d}$ to MUR supplementation 
$181(\mathrm{P}=0.010)$ suggested that the optimum inclusion level at this age was at 35,000 LSU(F)/kg, 182 where FCR was $2.6 \%$ lower than the control. In agreement with the FCR at $42 \mathrm{~d}$ of age, the 183 EPEF responded in the same way to MUR activity $(\mathrm{P}=0.016)$, being $6.7 \%$ higher than the 184 control when the diet was supplemented with $35,000 \mathrm{LSU}(\mathrm{F}) / \mathrm{kg}$. The liveability of the birds 185 was unaffected $(\mathrm{P}>0.05)$ by MUR dosage.

186 The footpad dermatitis score, determined at $35 \mathrm{~d}$ of age, was reduced in a dose dependent linear manner $(\mathrm{P}<0.001$; Table 3$)$ in agreement with the improved WG and FCR for the same period.

Table 3 here

Dietary MUR significantly alter the litter dry matter, $\mathrm{pH}, \mathrm{N}$ content or footpad dermatitis score $(\mathrm{P}>0.05$; Table 4). Fat retention increased in a dose dependent linear manner $(\mathrm{P}<0.001$; Table 4).

Table 4 here

197 There were no differences $(\mathrm{P}>0.05)$ in SA excretions. Exogenous MUR supplementation significantly improved $(\mathrm{P}<0.05)$ dietary AMEn, and the coefficients of retention of dry matter, organic matter and nitrogen (Table 5) in a quadratic manner.

Table 5 here 
203

204

205

206

207

208

209

210

211

212

213

214

215

216

217

218

219

220

221

222

223

224

225

226

227

\section{Discussion}

The positive responses in the growth performance variables and EPEF in this study are in accordance with recently published studies. When feeding the same levels of the same MUR product, Goodarzi Boroojeni et al. (2019) found a linear increase in WG and decrease in FCR at $35 \mathrm{~d}$ of age and the supplementation improved EPEF in similar way as in the present paper. Sais et al., (2019) reported reduced FCR in broilers fed MUR from day old to $36 \mathrm{~d}$ age. Most importantly, the improvement in FCR at $42 \mathrm{~d}$ of age in the current study agreed with the findings of Lichtenberg et al. (2017), who fed the same dosage of the same enzyme to broilers. The latter authors found an even greater improvement in final weight of birds, although they were fed much higher MUR dosages (225,000 and 450,000 LSU (F)/kg), although no changes at FCR were noted.

Studies on the use of MUR from different origins, e.g. modified rice expressing lysozyme (Humphrey et al., 2002) or hen egg-white (HEW) lysozyme (Abdel-Latif et al., 2017), in broiler diets have been reported to improve feed efficiency. However, Gong et al. (2017) found no effect on growth performance, but saw changes in the microbiome when feeding a HEW lysozyme preparation to broilers. Liu et al. (2010) and Zhang et al. (2010), reported improved growth when HEW lysozyme was fed to Clostridium perfringens challenged birds, but not in the unchallenged control group.

The variation in growth responses between published reports may be attributable to differences in dietary formulations, enzyme dose, application or the origin of the lysozyme or the simultaneous use of other enzymes. Given the diversity in origin between different lysozymes evaluated in vivo, it can be speculated that the mode of action can differ. In the current study, the microbial-derived product used was encoded by the MUR gene from the fungus Acremonium alcalophilum and was assessed to ensure it did not to possess any antibacterial activities at the intended doses (EFSA, 2018). Lichtenberg et al. (2017) showed an increase in 
228 feed efficiency, without any significant differences in the caecal microbiome for microbially229 derived MUR supplemented broiler diets.

230 In the current study, significant growth performance in response to dietary MUR was only 231 observed in birds after $21 \mathrm{~d}$ of age. This suggested that the beneficial effect of MUR was related 232 to the changing importance of the caeca in birds as they aged, as at $7 \mathrm{~d}$ of age the caeca 233 represents only $13 \%$ of the weight of the small intestine, whereas at $35 \mathrm{~d}$ it comprises $24 \%$ of 234 the small intestine (Yang et al., 2020). Apajalathi et al. (2002) reported that the numbers of 235 microbes reach $10^{11} / \mathrm{g}$ of caecal digesta and $10^{9} / \mathrm{g}$ of ileal digesta during the first three days 236 post hatch, and remain relatively stable for the following $34 \mathrm{~d}$. As feed intake and the absolute 237 size of the gastrointestinal tract (GIT) increases with the age of the birds, it is logical to assume 238 that the content of digesta, i.e. the total number of microbes in the GIT, increases 239 proportionally. The life span of bacteria is relatively short (Fuller, 1978) and a continuous and 240 natural bacterial turnover occurs, releasing bacterial cell debris into the GIT. Through this 241 process, in one generation, up to half of the pre-existing PGNs from the bacterial cell wall is 242 released and recovered (Reith and Mayer, 2011). However, it is still unclear what happens with 243 the remaining PGNs, and, as birds age, their GIT may accumulate bacterial cell debris, 244 including PGNs. This might explain why the improvement of growth performance was only 245 seen in older birds in the present study.

246 Metabolisable energy is a measurement of the available energy from dietary carbohydrates, 247 fats and proteins, hence, it was expected that an improvement in nutrient retention coefficients 248 would improve dietary AMEn (Woods et al., 2020). The main ingredient in the diets was wheat, 249 which may cause an increase in digesta viscosity due to high non-starch polysaccharide (NSP) 250 content, that can reduce energy and nutrient availability (Pirgozliev et al., 2015). Although 251 viscosity was not measured in the reported study, the quadratic response between AMEn and 252 the majority of the nutrients suggested that MUR may have an impact on digesta viscosity. 
253 However, further research into any interaction between MUR and other feed additives is

254 warranted. Zanella et al. (1999) found that metabolisable energy and nutrient digestibility

255 differed when determined using ileal digesta or excreta. This may provide an alternative

256 explanation to the quadratic responses seen to MUR in the current study, where AMEn was

257 performed on excreta and was linear, whereas the Goodarzi Boroojeni et al., (2019) study used

258 digesta samples for evaluation.

259 In addition, increased digesta viscosity has been shown to reduce conjugated bile acids,

260 affecting fat emulsification and digestibility (Langhout et al., 1997). In the present study, fat

261 retention increased with MUR in a dose dependent linear manner. Sais et al. (2019) showed

262 that MUR inclusion increased ileal apparent digestibility of fat and increased fat-soluble

263 vitamin $\mathrm{A}$ in plasma at $9 \mathrm{~d}$ of age. This suggested that MUR improves fat digestion and

264 absorption in young birds. Goodarzi Boroojeni et al. (2019) observed that supplementing MUR

265 in a 30\% wheat-based diet containing exogenous carbohydrase showed improvement in the

266 apparent ileal digestibility of fat in a linear fashion after $35 \mathrm{~d}$ of supplementation. Goodarzi

267 Boroojeni et al. (2019) suggested that MUR might catalyse the depolymerisation of

268 peptidoglycans from bacterial cell debris and reduce its accumulation in the gut, thus improving

269 nutrient utilisation. During this process, negatively charged peptidoglycans (Marquis and

270 Bender, 1990) may lose their charge, reducing the number of interactions with fat micelles,

271 thus benefiting fat absorption.

272 Sialic acid has been used as a marker to measure the dynamics of mucin secretions in excreta 273 in enzyme fed birds. Early work with phytase (Cowieson et al., 2004; Pirgozliev et al., 2011)

274 showed a reduction in SA secretion due to supplementation, although feeding an enzyme 275 mixture to broilers (Abdulla et al., 2016, 2017) did not change the concentration of SA secreted.

276 In the current study, the SA data measured in excreta after $17 \mathrm{~d}$ of supplementation did not 277 indicate differences due to MUR supplementation. Goodarzi Boroojeni et al. (2019) did not 
278

279

280

281

282

283

284

285

286

287

288

289

290

291

292

293

294

295

296

297

298

299

300

301

302

observe any significant differences in goblet cell numbers at the jejunal and ileal level after 35 d supplementation with microbial MUR in a diet containing other enzymes (phytase and xylanase). However, Sais et al. (2019) detected an increase in goblet cell numbers after $36 \mathrm{~d}$ of microbial MUR supplementation in a diet without other feed enzymes. This can probably be explained by direct or indirect changes promoted by MUR in the intestinal ecosystem or in the release of bioactive factors. The variability in response may be due to the sampling region (small intestine or excreta), maturity of the birds, method of analyses or type of diet (with or without additives), and further research is needed to explore the mode of action of this microbial MUR and its role in improving gastrointestinal function.

Improvements in litter quality and footpad dermatitis contribute to welfare in poultry. The current study showed an improvement in FPD when animals were supplemented with microbial MUR, but there was no impact on litter moisture and $\mathrm{NH}_{3}$ concentration. An increase in litter moisture and $\mathrm{NH}_{3}$ are the main predisposing factors for footpad dermatitis in broilers (Dawkins et al., 2004), although there was no obvious correlation between the improved FPD and the litter parameters. Mirza et al. (2016) reported that good litter scores (based on physical appearance) were not related to litter $\mathrm{NH}_{3}$ or $\mathrm{pH}$, showing that scoring per se is of limited value in terms of lowering FPD incidences in poultry production. This suggests that dietary MUR may provide better nutrient availability and have a direct positive impact on the development of skin of the foot pad in poultry.

It can be concluded that the exogenous microbial MUR (Balancius ${ }^{\mathrm{TM}}$ ) used in this study was effective in improving growth performance and welfare in broilers. This was attributed to improved dietary nutrient and energy availability. There is a need to study potential interactions of MUR in combination with other exogenous enzymes, plant extracts and feed additives. Strategies to incorporate MUR with other feed ingredients in poultry diets, in order to improve production and welfare, may increase the profitability of broiler production. 


\section{References}

305

306

307

308

309

310

311

312

313

314

315

316

317

318

319

320

321

322

Abdulla, J. M., S. P. Rose, A. M. Mackenzie, S. G. Ivanova, G. P. Staykova, and V. R. Pirgozliev. 2016. "Nutritional Value of Raw and Micronised Field Beans (Vicia faba L. var. minor) With and Without Enzyme Supplementation Containing Tannase for Growing Chickens.” Archives of Animal Nutrition $70 \quad$ (5): 350-363. doi:10.1080/1745039X.2016.1214344.

Abdulla, J. M., S. P. Rose, A. M. Mackenzie, and V. R. Pirgozliev. 2017. "Feeding Value of Field Beans (Vicia faba L. var. minor) With and Without Enzyme Containing Tannase, Pectinase and Xylanase Activities for Broilers." Archives of Animal Nutrition 71 (2): 150-164. doi:10.1080/1745039X.2017.1283823.

Adeola, O., and A. J. Cowieson. 2011. "Board-Invited Review: Opportunities and Challenges in Using Exogenous Enzymes to Improve Non-Ruminant Animal Production.” Journal of Animal Science 89 (10): 3189-3218. doi:10.2527/jas.2010-3715.

Apajalahti, J. H. A., H. Kettunen, A. Kettunen, W. E. Holben, P. H. Nurminen, N. Rautonen, and M. Mutanen. 2002. "Culture-Independent Microbial Community Analysis Reveals that Inulin in the Diet Primarily Affects Previously Unknown Bacteria in the Mouse Cecum." Applied and Environmental Microbiology 68 (10): 4986-4995. doi:10.1128/AEM.68.10.4986-4995.2002.

Abdel-Latif, M. A., H. Ali, A. R. Elbestawy, R. Ghanem, S. A. Mousa, and H. S. A. El-Hamid. 2017. Exogenous Dietary Lysozyme Improves the Growth Performance and Gut Microbiota in Broiler Chickens Targeting the Antioxidant and Non-specific Immunity mRNA Expression. PLOS ONE 12:E0185153. 
327 Cowieson, A. J., T. Acamovic, and M. R. Bedford. 2004. "The Effects of Phytase and Phytic Acid on the Loss of Endogenous Amino Acids and Minerals from Broiler Chickens." British Poultry Science 45 (1): 101-108. doi:10.1080/00071660410001668923.

Da Costa, M., J. L. Grimes, E. Oviedo-Rondón, I. Barasch, C. Evans, M. Dalmagro, and J. 
351 Hocking, P.M., Mayne, R.K., Else, R.W., French, N.A., and Gatcliffe, J. 2008. "Standard

352

353

354

355

356

357

358

359

360

361

362

363

364

365

366

367

368

369

370

371

372

373

374 European footpad dermatitis scoring system for use in turkey processing plants". World's Poultry Science Journal, 64: 323-328. https://doi.org/10.1017/S0043933908000068

Humphrey, B. D., N. Huang, and K. C. Klasing. 2002. "Rice Expressing Lactoferrin and Lysozyme Has Antibiotic-Like Properties When Fed to Chicks." The Journal of Nutrition 132 (6): 1214-1218. doi:10.1093/jn/132.6.1214.

Jourdian, G., L. Dean, and S. Roseman. 1971. “A Periodate-Resorcinol Method for the Quantitative Estimation of Free Sialic Acids and Their Glycosides." The Journal of Biological Chemistry 246 (2): 430-435.

Fuller, R. 1978. "Epithelial Attachment and Other Factors Controlling the Colonization of the Intestine of the Gnotobiotic Chicken by Lactobacilli." Journal of Applied Bacteriology 45 (3): 389-395. doi: 10.1111/j.1365-2672.1978.tb04240.x.

Langhout, D. J., J. B. Schutte, C. Geerse, A. K. Kies, J. De Jong, and M. W. A. Verstegen. 1997. "Effects on Chick Performance and Nutrient Digestibility of an Endo-Xylanase Added to a Wheat and Rye-Based Diet in Relation to Fat Source." British Poultry Science 38 (5): 557-563. doi: 10.1080/00071669708418036.

Lichtenberg, J., E. Perez Calvo, K. Madsen, T. Østergaard Lund, F. Kramer Birkved, S. van Cauwenberghe, M. Mourier, L. Wulf-Andersen, A. J. M. Jansman, and R. LopezUlibarri. 2017. "Safety Evaluation of a Novel Muramidase for Feed Application." Regulatory Toxicology and Pharmacology 89: 57-69. doi:10.1016/j.yrtph.2017.07.014.

Liu, D., Y. Guo, Z. Wang, and J. Yuan. 2010. “Exogenous Lysozyme Influences Clostridium Perfringens Colonization and Intestinal Barrier Function in Broiler Chickens.” Avian Pathology 39 (1): 17-24. doi:10.1080/03079450903447404. 
375 Marquis, R.E., and G.R. Bender. 1990. "Compact Structure of Cortical Peptidoglycans from 376 Bacterial Spores." Canadian Journal of Microbiology 36 (6): 426-429.

Mirza, M. W., V. Pirgozliev, S. P. Rose, and N. H. C. Sparks. 2016. "Dietary Modelling of Nutrient Densities: Effect and Response in Different Growing Phases on Growth Performance, Nutrient Digestibility, Litter Quality and Leg Health in Turkey Production." Journal of World's Poultry Research 6 (3): 161-190.

Pirgozliev, V., M. R. Bedford, and T. Acamovic. 2010. "Effect of Dietary Xylanase on Energy, Amino Acid and Mineral Metabolism, and Egg Production and Quality in Laying $\begin{array}{llllll}\text { Hens." } & \text { British } & \text { Poultry } & \text { Science } & 51 & \text { (5). }\end{array}$ HTTPS://DOI.ORG/10.1080/00071668.2010.514325

Pirgozliev, V., M. R. Bedford, T. Acamovic, and M. Allimehr. 2011. "The Effects of Supplementary Bacterial Phytase on Dietary True Metabolisable Energy, Nutrient Digestibility and Endogenous Losses in Precision Fed Turkeys.” British Poultry Science 52 (2): 214-220. doi:10.1080/00071668.2011.560594.

Pirgozliev, V., A. Beccaccia, S. P. Rose, and D. Bravo. 2015. "Partitioning of Dietary Energy of Chickens Fed Maize- or Wheat-Based Diets With and Without a Commercial Blend of Phytogenic Feed Additives." Journal of Animal Science 93 (4): 1695-1702. doi:10.2527/jas2014-8175.

Pirgozliev, V., S. P. Rose, and S. Ivanova. 2019 "Feed Additives in Poultry Nutrition." Bulgarian Journal of Agricultural Science 25 (1): 8-11.

Ravindran, V. 2013. “Feed Enzymes: The Science, Practice and Metabolic Realities.” Journal of Applied Poultry Research 22 (3): 628-836. doi:10.3382/japr.2013-00739. 
397 Reith, J., and C. Mayer. 2011. "Peptidoglycan Turnover and Recycling in Gram-positive

398

399

400

401

402

403

404

405

406

407

408

409

410

411

412

413

414

415

416

417

418

419 Bacteria." Applied Microbiology and Biotechnology 92 (1): 1-11. doi:10.1007/s00253011-3486-x.

Sais, M., A. C. Barroeta, P. López-Colom, M. Nofrarías, N. Majó, R. Lopez-Ulibarri, E. Pérez Calvo, and S. M. Martín-Orúe. 2019. "Evaluation of Dietary Supplementation of a Novel Microbial Muramidase on Gastrointestinal Functionality and Growth Performance in Broiler Chickens." Poultry Science 99 (1): 235-245. doi:10.3382/ps/pez466.

Yang, Z., V. R. Pirgozliev, S. P. Rose, S. Woods, H. M. Yang, Z. Y. Wang, and M. R. Bedford. 2020. "Effect of Age on the Relationship Between Metabolizable Energy and Digestible Energy for Broiler Chickens." Poultry Science 99 (1): 320-330. doi:10.3382/ps/pez495.

Woods, S. L., S. Sobolewska, S. P. Rose, I. M. Whiting, A. Blanchard, C. Ionescu, D. Bravo, and V. Pirgozliev. 2020. "Effect of Feeding Different Sources of Selenium on Growth Performance and Antioxidant Status of Broilers." British Poultry Science - just accepted. doi:10.1080/00071668.2020.1716301.

Zanella, I., N. K. Sakomura, F.G. Silversides, A. Fiqueirdo, and M. Pack. 1999. "Effect of Enzyme Supplementation of Broiler Diets Based on Corn and Soybeans." Poultry Science 78 (4): 561-568. doi: org/10.1093/ps/78.4.561.

Zhang, G., G. F. Mathis, C. L. Hofacre, P. Yaghmaee, R. A. Holley, and T. D Durance. 2010. "Effect of a Radiant Energy-Treated Lysozyme Antimicrobial Blend on the Control of Clostridial Necrotic Enteritis in Broiler Chickens.” Avian Diseases 54 (4): 1298-1300. doi:10.1637/9370-041410-ResNote.1. 
421 Table 1. Composition and nutritive values of the experimental diets

\begin{tabular}{|c|c|c|c|c|}
\hline Ingredients $(\mathrm{g} / \mathrm{kg})$ & Starter & Grower & Finisher 1 & Finisher 2 \\
\hline Wheat & 586.9 & 680.7 & 700.9 & 724.9 \\
\hline Soybean meal (CP 480) & 342.7 & 247.1 & 228.3 & 205.8 \\
\hline Soybean oil & 36.3 & 41.9 & 42.4 & 43.2 \\
\hline Limestone & 12.8 & 11.3 & 10.7 & 9.9 \\
\hline Monocalcium phosphate & 9.2 & 7.5 & 6.6 & 5.6 \\
\hline Lysine HCL & 2.7 & 3.3 & 3.1 & 2.9 \\
\hline Methionine DL & 3.4 & 3.0 & 2.8 & 2.5 \\
\hline L-Threonine & 1.3 & 1.5 & 1.4 & 1.3 \\
\hline Salt & 1.9 & 1.6 & 1.7 & 1.7 \\
\hline Sodium bicarbonate & 2.5 & 1.8 & 1.7 & 1.7 \\
\hline Xylanase $^{1}$ & 0.0075 & 0.0075 & 0.0075 & 0.0075 \\
\hline Phytase $^{2}$ & 0.0100 & 0.0100 & 0.0100 & 0.0100 \\
\hline Premix (VitMin) ${ }^{3}$ & 0.2000 & 0.2000 & 0.2000 & 0.2000 \\
\hline \multicolumn{5}{|l|}{ Calculated values } \\
\hline $\mathrm{ME}(\mathrm{MJ} / \mathrm{kg})$ & 12.70 & 13.20 & 13.29 & 13.40 \\
\hline Crude protein $(\mathrm{g} / \mathrm{kg})$ & 235 & 198 & 190 & 181 \\
\hline Ether extract $(\mathrm{g} / \mathrm{kg})$ & 51 & 57 & 57 & 58 \\
\hline Ash $(g / k g)$ & 53 & 45 & 43 & 40 \\
\hline Digestible Lys (g/kg) & 12.9 & 11.0 & 10.4 & 9.7 \\
\hline Digestible Met+Cys $(\mathrm{g} / \mathrm{kg})$ & 9.5 & 8.4 & 8.0 & 7.6 \\
\hline $\mathrm{Ca}(\mathrm{g} / \mathrm{kg})$ & 10.0 & 9.0 & 8.5 & 8.0 \\
\hline Available P (g/kg) & 5.0 & 4.5 & 4.3 & 4.0 \\
\hline \multicolumn{5}{|l|}{ Determined values } \\
\hline $\mathrm{DM}(\mathrm{g} / \mathrm{kg})$ & 904 & 902 & 898 & 898 \\
\hline GE (MJ/kg) & 16.59 & 16.94 & 17.02 & 16.95 \\
\hline Crude protein $(\mathrm{g} / \mathrm{kg})$ & 245 & 198 & 200 & 174 \\
\hline Ether extract $(\mathrm{g} / \mathrm{kg})$ & 50 & 58 & 56 & 56 \\
\hline $\operatorname{Ash}(\mathrm{g} / \mathrm{kg})$ & 54 & 53 & 47 & 43 \\
\hline Xylanase (FXU/kg) & 183 & 185 & 177 & 158 \\
\hline Phytase (FYT/kg) & 2427 & 2720 & 2408 & 2537 \\
\hline
\end{tabular}

422

4231 Ronozyme ${ }^{\circledR}$ WX2000: minimum 2000 FXU/ g endo-1,4-beta-xylanase; 1 xylanase unit 424 (FXU) is defined as the amount of enzyme that releases $7.8 \mu \mathrm{mol}$ of reducing sugar (xylose 425 equivalents) from azo-wheat arabinoxylan per minute at $\mathrm{pH} 6.0$ and $50 \mathrm{C}$

$4262^{2}$ Ronozyme ${ }^{\circledR}$ HiPhos 20000GT: minimum $20000 \mathrm{FYT} / \mathrm{g} ; 1$ phytase unit (FYT) is defined 427 as the amount of enzyme that releases $1 \mu \mathrm{mol}$ of inorganic phosphate from phytate per minute 428 under reaction conditions with a phytate concentration of $5.0 \mathrm{mM}$ and $\mathrm{pH} 5.5$ and temperature $42937^{\circ} \mathrm{C}$.

$430{ }^{3}$ The vitamin and mineral premix contained vitamins and trace elements to meet breeder's 431 recommendation (Aviagen Ltd., Edinburgh, UK). The premix provided is as follows (units/kg 432 diet): retinol $3600 \mu \mathrm{g}$, cholecalciferol $125 \mu \mathrm{g}, \alpha$ - tocopherol $34 \mathrm{mg}$, menadione $3 \mathrm{mg}$, thiamine $4332 \mathrm{mg}$, riboflavin $7 \mathrm{mg}$, pyridoxine $5 \mathrm{mg}$, cobalamin $15 \mu \mathrm{g}$, nicotinic acid $50 \mathrm{mg}$, pantothenic 434 acid $15 \mathrm{mg}$, folic acid $1 \mathrm{mg}$, biotin $200 \mu \mathrm{g}$, iron $80 \mathrm{mg}$, copper $10 \mathrm{mg}$, manganese $100 \mathrm{mg}$, 435 cobalt $0.5 \mathrm{mg}$, zinc $80 \mathrm{mg}$, iodine $1 \mathrm{mg}$, selenium $0.2 \mathrm{mg}$ and molybdenum $0.5 \mathrm{mg}$. 
436 Table 2. Analysed muramidase activity in samples of the experimental diets

Measured activity $(\mathrm{LSU}(\mathrm{F}) / \mathrm{kg}$

Treatment Inclusion level

$(\mathrm{LSU}(\mathrm{F}) / \mathrm{kg})^{*} \quad$ Starter $\quad$ Grower $\quad$ Finisher $1 \quad$ Finisher 2

Control 0

$\begin{array}{lllll}\text { Low } & 25000 & 26472 & 26469 & 30186\end{array}$

$\begin{array}{lllll}\text { Medium } \quad 35000 & 31422 & 39569 & 38106 & 45180\end{array}$

High $\quad 45000 \quad 33932 \quad 49049 \quad 53036 \quad 51650$

$437 *$ One unit of muramidase (LSU(F)) is the amount of enzyme that increases the fluorescence 438 of a $12.5 \mu \mathrm{g} / \mathrm{ml}$ fluorescein-labelled peptidoglycan suspension by a value that corresponds to 439 the fluorescence of $0.077 \mathrm{mM}$ fluorescein isothiocyanate (FITC), per minute at $\mathrm{pH} 7.5$ and $44030^{\circ} \mathrm{C}$.

441

442 Table 3. Effect of different inclusion levels of muramidase on growth performance of broiler 443 chickens

\begin{tabular}{|c|c|c|c|c|c|c|c|c|}
\hline \multirow[b]{2}{*}{$\begin{array}{l}\text { Treatment } \\
\text { groups } 1\end{array}$} & \multirow[b]{2}{*}{ Control } & \multirow[b]{2}{*}{ Low } & \multirow[b]{2}{*}{ Medium } & \multirow[b]{2}{*}{ High } & \multirow[b]{2}{*}{ SEM } & \multicolumn{3}{|c|}{ Probability } \\
\hline & & & & & & $\mathrm{P}$ & $\mathrm{L}$ & Q \\
\hline & \multicolumn{8}{|c|}{ Starter period ( 1 to $10 \mathrm{~d}$ old $)$} \\
\hline $\begin{array}{l}\text { Feed intake } \\
(\mathrm{g} / \mathrm{b})\end{array}$ & 294 & 293 & 296 & 295 & 2.2 & 0.800 & 0.610 & 0.993 \\
\hline $\begin{array}{l}\text { Weight gain } \\
(\mathrm{g} / \mathrm{b})\end{array}$ & 216 & 222 & 223 & 223 & 2.5 & 0.173 & 0.053 & 0.277 \\
\hline \multirow[t]{2}{*}{$\begin{array}{l}\text { Feed } \\
\text { conversion } \\
\text { ratio }^{2}\end{array}$} & 1376 & 1325 & 1329 & 1325 & 0.0248 & 0.394 & 0.183 & 0.349 \\
\hline & \multicolumn{8}{|c|}{ Grower period ( 10 to $21 \mathrm{~d}$ old $)$} \\
\hline $\begin{array}{l}\text { Feed intake } \\
(\mathrm{g} / \mathrm{b})\end{array}$ & 1142 & 1134 & 1136 & 1139 & 7.9 & 0.885 & 0.850 & 0.463 \\
\hline $\begin{array}{l}\text { Weight gain } \\
(\mathrm{g} / \mathrm{b})\end{array}$ & 933 & 956 & 937 & 935 & 14.4 & 0.663 & 0.809 & 0.402 \\
\hline \multirow{2}{*}{$\begin{array}{l}\text { Feed } \\
\text { conversion } \\
\text { ratio }\end{array}$} & 1.218 & 1.181 & 1.224 & 1.233 & 0.0317 & 0.670 & 0.538 & 0.469 \\
\hline & \multicolumn{8}{|c|}{ Finisher period 1 ( 21 to $42 \mathrm{~d}$ old $)$} \\
\hline $\begin{array}{l}\text { Feed intake } \\
(\mathrm{g} / \mathrm{b})\end{array}$ & 2961 & 2972 & 2951 & 2978 & 16.5 & 0.682 & 0.698 & 0.632 \\
\hline $\begin{array}{l}\text { Weight gain } \\
(\mathrm{g} / \mathrm{b})\end{array}$ & $1957^{\mathrm{a}}$ & $2008^{b}$ & $2003^{b}$ & $2014^{b}$ & 12.4 & 0.007 & 0.004 & 0.108 \\
\hline \multirow{2}{*}{$\begin{array}{l}\text { Feed } \\
\text { conversion } \\
\text { ratio }\end{array}$} & $1.492^{\mathrm{a}}$ & $1.454^{\mathrm{b}}$ & $1.457^{\mathrm{b}}$ & $1.451^{\mathrm{b}}$ & 0.0067 & $<0.001$ & $<0.001$ & 0.019 \\
\hline & \multicolumn{8}{|c|}{ Overall period ( 1 to $42 \mathrm{~d}$ old $)$} \\
\hline
\end{tabular}


$\begin{array}{lllllllll}\text { Feed intake } & 4565 & 4536 & 4539 & 4562 & 26.3 & 0.809 & 0.970 & 0.331\end{array}$

$(\mathrm{g} / \mathrm{b})$

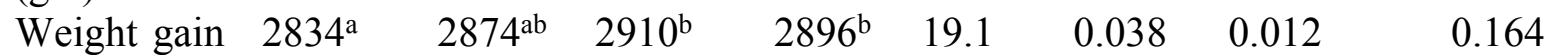

$(\mathrm{g} / \mathrm{b})$

Feed

conversion

ratio

Liveability

$(\%)$

$\mathrm{EPEF}^{3}$

\section{$1.579^{\mathrm{a}} \quad 1.551^{\mathrm{b}} \quad 1.538^{\mathrm{b}}$}

$1.547^{\mathrm{b}}$

$0.0069<0.001<0.001 \quad 0.010$

444

445

${ }^{1}$ Control: control diet, low (25,000 LSU(F)/kg muramidase), medium (35,000 LSU(F)/kg 446 muramidase), high (45,000 LSU(F)/kg muramidase). ${ }^{2}$ Gram feed intake per gram weight gain. $447 \quad{ }^{3}$ European poultry efficiency factor: averaged grams gained per day $\times$ survival rate $(\%) \div$ feed 448 conversion ratio $\times 10$. Data are means of 24 replicate pens with 20 birds per pen. $P$ value 449 describes significance between treatments determined by ANOVA. Linear (L) and quadratic 450 (Q) effects of dietary treatment. Results are statistically significant when $\mathrm{P} \leq 0.05$.

451

452 Table 4. Effect of dietary treatment on dry matter (DM), $\mathrm{pH}$ and $\mathrm{N}$ of litter, litter and footpad 453 scores at 35 days of age

\begin{tabular}{|c|c|c|c|c|c|c|c|c|}
\hline \multirow[b]{2}{*}{$\begin{array}{l}\text { Treatment } \\
\text { groups }{ }^{1}\end{array}$} & \multirow[b]{2}{*}{ Control } & \multirow[b]{2}{*}{ Low } & \multirow[b]{2}{*}{ Medium } & \multirow[b]{2}{*}{ High } & \multirow[b]{2}{*}{ SEM } & \multicolumn{3}{|c|}{ Probability } \\
\hline & & & & & & $\mathrm{P}$ & $\mathrm{L}$ & Q \\
\hline $\begin{array}{l}\text { Dry matter litter } \\
(\mathrm{g} / \mathrm{kg})\end{array}$ & 0.667 & 0.652 & 0.643 & 0.654 & 0.0179 & 0.804 & 0.539 & 0.452 \\
\hline $\mathrm{pH}$ litter & 7.35 & 7.44 & 7.53 & 7.46 & 0.120 & 0.770 & 0.451 & 0.510 \\
\hline $\mathrm{N}$ litter $(\mathrm{g} / \mathrm{kg})$ & 40.8 & 41.8 & 40.5 & 40.9 & 0.81 & 0.693 & 0.808 & 0.680 \\
\hline Litter score & 3.27 & 3.14 & 3.20 & 3.12 & 0.065 & 0.332 & 0.175 & 0.726 \\
\hline Footpad score & 26.0 & 24.0 & 13.0 & 15.8 & 4.45 & 0.123 & 0.039 & 0.590 \\
\hline
\end{tabular}

454

455

${ }^{1}$ Control: control diet, low (25,000 LSU (F)/kg muramidase), medium (35,000 LSU (F)/kg 456 muramidase), high (45,000 LSU (F)/kg muramidase). Data are means of 24 replicate pens with 457 20 birds per pen. $\mathrm{P}$ value describes significance between treatments determined by ANOVA. Linear (L) and quadratic (Q) effects of dietary treatment. Results are statistically significant when $\mathrm{P} \leq 0.05$.

460

Table 5. Effect of dietary treatment on N-corrected apparent metabolisable energy (AMEn), 462 dry matter (DMR), organic matter (OMR), N (NR), fat (FR) retention coefficients and sialic 463 acid (SA) excretions.

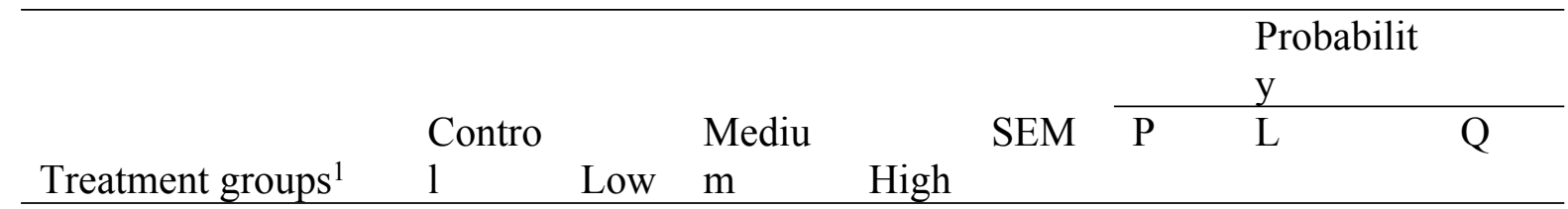




\begin{tabular}{|c|c|c|c|c|c|c|c|c|}
\hline & & 12.6 & & 13.2 & 0.162 & 0.06 & 0.985 & 0.00 \\
\hline \multirow[t]{2}{*}{ AMEn (MJ/kg DM) } & 12.98 & 2 & 12.96 & 6 & & 2 & & 7 \\
\hline & & 0.68 & & 0.71 & 0.010 & 0.10 & 0.701 & 0.01 \\
\hline \multirow[t]{2}{*}{ DMR } & 0.705 & 1 & 0.696 & 7 & 4 & 7 & & 6 \\
\hline & & 0.70 & & 0.74 & 0.009 & 0.05 & 0.844 & 0.00 \\
\hline \multirow[t]{2}{*}{ OMR } & 0.729 & 6 & 0.725 & 3 & 5 & 8 & & 7 \\
\hline & & 0.57 & & 0.61 & 0.014 & 0.17 & 0.889 & 0.04 \\
\hline \multirow[t]{2}{*}{ NR } & 0.592 & 1 & 0.577 & 3 & 0 & 5 & & 5 \\
\hline & & 0.81 & & 0.84 & 0.010 & 0.09 & 0.050 & 0.18 \\
\hline \multirow[t]{2}{*}{ FR } & 0.815 & 1 & 0.834 & 3 & 4 & 9 & & 7 \\
\hline & & & & & 0.074 & 0.42 & 0.408 & 0.42 \\
\hline \multirow[t]{2}{*}{$\mathrm{SA}(\mu \mathrm{g} / \mathrm{g})$} & 1.88 & 2.00 & 1.91 & 1.96 & & 3 & & 2 \\
\hline & & & & & 0.22 & 0.10 & 0.871 & 0.22 \\
\hline SA total $(\mu \mathrm{g} / 24 \mathrm{~h})$ & 32.8 & 37.1 & 31.8 & 34.0 & & 8 & & 5 \\
\hline
\end{tabular}

$465{ }^{1}$ Control: control diet, low (25,000 LSU(F)/kg muramidase), medium (35,000 LSU(F)/kg 466 muramidase), high (45,000 LSU(F)/kg muramidase). Data are means of 24 replicate pens with 4672 birds per pen. $\mathrm{P}$ value describes significance between treatments determined by ANOVA. 468 Linear (L) and quadratic (Q) effects of dietary treatment. Results are statistically significant 469 when $\mathrm{P}<0.05$. 